\title{
33. 蛍光体の違いによるヨード造影剤のX線吸収差
}

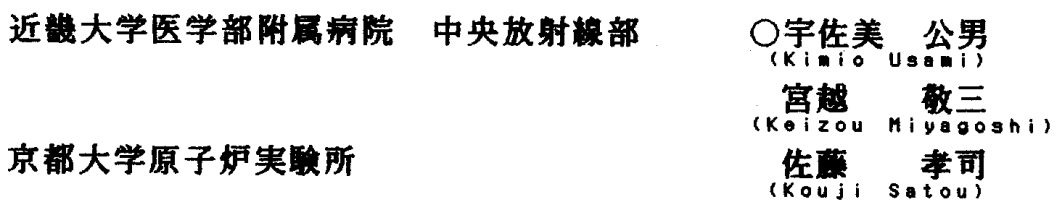

【目的】現在、X線撮影系には、多㮔の蛍光体が使用されているが、その特性は蛍光体の吸収係数 の違い、入射するX楾スペクトルとの関保により異なると思われる。今回、コントラスト特性に直接 関係する蛍光体のX線エネルギー吸收羑を中心に、理詥的解析を行った。又、散乱線吸収についても 喻討した。

【方法】連続X線をBirch式により算出し、照射野 $6 \mathrm{~cm} \times 6 \mathrm{~cm}$ にて、ヨード造影剂 $(300 \mathrm{mg} / \mathrm{ml} ;$ 厚さ2m $\times$ 巾 $8 \mathrm{~mm})$ の入った水フナントム $(10 \mathrm{~cm} \times 10 \mathrm{~cm} \times 5 \mathrm{~cm} /$ 厚 $)$ に入射させ、射出面にてポジション $1 \mathrm{~mm}$ 毎に計 40 個の水及びヨード透過後のスペクトルを求めた。このとき、ファントム中での散乱はモンテカル 口法により計算し、射出する散乱線スペクトルを得た。又、直接線は吸取保数により計萛で求め、両 者を加え射出スペクトルとした。次に、このスペクトルを蛍光体 $\left({ }^{74} \mathrm{~W} \cdot{ }^{64} \mathrm{Gd} \cdot{ }^{39} \mathrm{Y}\right)$ にポジショ ン每に入射させ吸収スペクトルを求めエネルギー吸収量を萛出した。ここでX線エネルギー吸収量比 は、造影剂直下のポジションでの吸収量を $\mathrm{A}$ 、水直下での吸収量を Bとし、B／Aの值と定義する。

【結果 考察】水と造影剂とのエネルギ一吸収量比(B/A)は、直接コントラストに関与する值となる。 Fig.1は、この此率につき管電圧を横軸とし示したものである。Yが最も比車が大きく、コントラスト 特性に優れていることを示しており、次いで、W, $\mathrm{Gd}$ d順となっている。これは觉光体に入射するス ペクトルと、蛍光体の吸収保数の遠いにより生じると考えられるが、この関保を各管電圧のWの值を 1にノーマライズしたFig.2より考える。Gdは60kVにて比事が低下し、80kVより再び上昇する。これ は、50.2keVのG dの吸収端、69.5keVのWの吸収端の影籍と考えられる。Yは80kVより比事の上开が

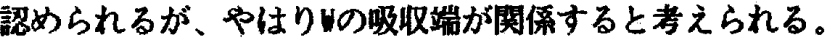

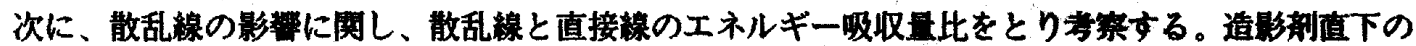
ポジションでの比事を(I)、水直下の比率を(Water)とし、Fig.3に示す。Gdは60kV〜100kVにおいて、 他と比べ散乱湶の比率が小さくなっている。これ は散乱線の平均エネルギーが直接線に比べやや低 く、蛍光体の原子番号の臬いによりその影管が翼 なるためと考えられる。

この梾に、蛍光体のX線エネルギー吸収特性は 入射するスペクトルと蛍光体の吸収保数により決 まる。又、近年多く使用される G dは、W，Yと 比し、コントラスト特性に少るが、散乱線の影篦 は受けにくい蛍光体であると考えられる。

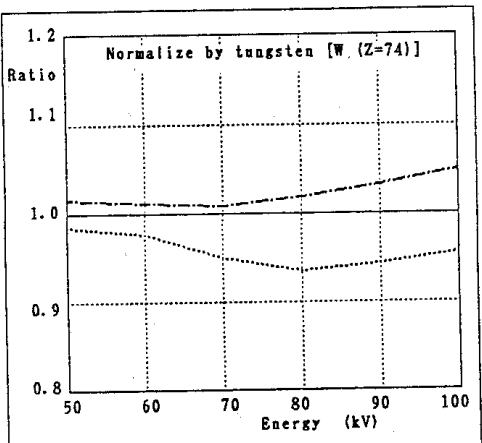

Fig.2

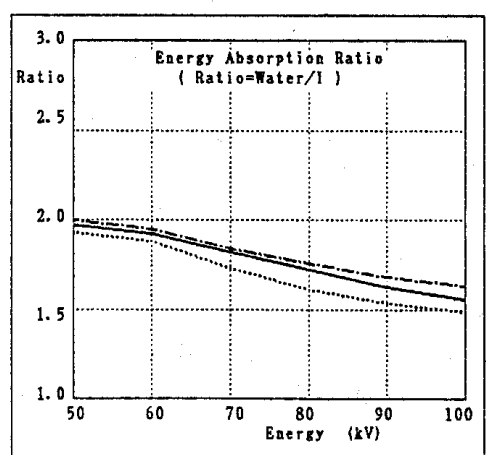

Fig.1

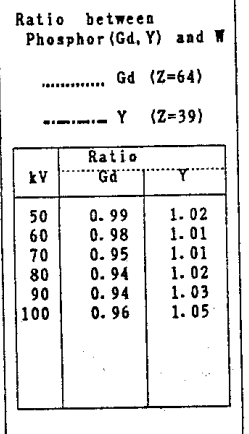

\begin{tabular}{c|c|c|}
\hline & Gd & $T$ \\
\hline 0 & 0.99 & 1.02 \\
0 & 0.98 & 1.01 \\
0 & 0.95 & 1.01 \\
0 & 0.94 & 1.02 \\
0 & 0.94 & 1.03 \\
0 & 0.96 & 1.05 \\
& & \\
& & \\
\hline
\end{tabular}
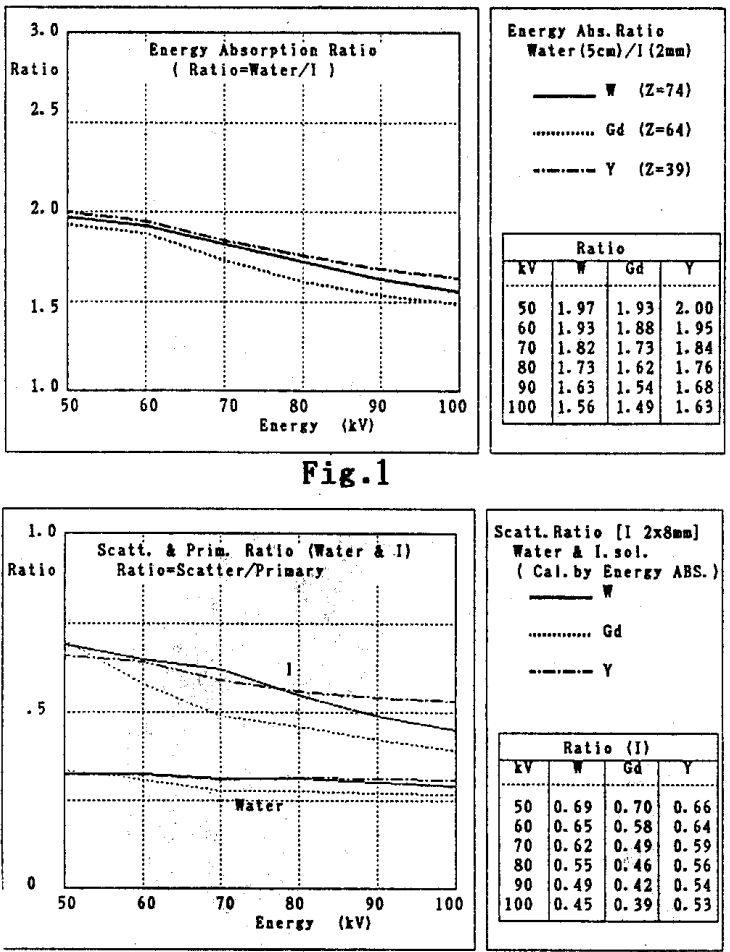

Fig. 3 